\title{
Effectiveness of Vitamin D Supplementation for Cardiovascular Health Outcomes
}

\author{
Panagiota Veloudi Graeme Jones James E. Sharman \\ Menzies Institute for Medical Research, University of Tasmania, Hobart, TAS, Australia
}

\section{Keywords}

Vitamin D supplementation · Cardiovascular health · Randomized controlled trials · Blood pressure $\cdot$ Large artery stiffness

\begin{abstract}
There is a plausible physiological theory, supported by many observational studies, that vitamin D supplementation should be effective for improving cardiovascular end points, such as blood pressure (BP), large artery stiffness, atherosclerosis, endothelial function and clinical events. However, results from randomised controlled trials (RCTs) have been inconsistent. In this review, we evaluated the evidence regarding the effectiveness of vitamin D supplementation for cardiovascular surrogate and hard clinical end points. RCTs were assessed in terms of sample size, duration of supplementation, baseline vitamin D level inclusion criteria (i.e., absence of vitamin $D$ deficiency), dosage of vitamin $D$ and population under investigation. Forty-five RCTs were identified. Eight RCTs with BP and 6 RCTs with large artery stiffness as the end points were found to comply with guidelines for the optimal design of clinical trials evaluating nutrient effects. Only 2 of the RCTs with an optimal design were effective in decreasing BP with vitamin D supplementation, although these were of moderate sample size $(<150)$ and very short duration ( 8 weeks for both), whilst no RCT was effective in reducing large artery stiffness. Similar results were observed for atherosclerotic and endothelial function markers as end points. Only 1 RCT reported cardiovascular events as an end point and found neither increased nor decreased incident cardiovascular events over 7 years of follow-up. In conclusion, results from published RCTs indicate that vitamin D supplementation is ineffective in improving cardiovascular health among various patient populations, including in the presence or absence of vitamin D deficiency.


Veloudi et al.: Effectiveness of Vitamin D Supplementation for Cardiovascular Health Outcomes

\section{Introduction}

Vitamin D (VitD), a lipid-soluble vitamin, plays a well-recognised role in musculoskeletal health [1,2], but evidence also suggests a critical role in blood pressure (BP) regulation and vascular health [3]. In vivo and in vitro studies have suggested a number of pathways by which VitD could directly benefit the vasculature [4-6] in addition to acting as a negative regulator of the renin-angiotensin system to influence BP control $[7,8]$ and modify large artery stiffness [9]. Observational data during the last decade suggest a relationship of low VitD levels with cardiovascular end points, including coronary artery disease, myocardial infarction (MI), heart failure (HF), stroke and cardiovascular death. Additionally, more than 4 decades of cross-sectional research generally show a consistent inverse association between VitD levels and surrogate cardiovascular markers of BP, large artery stiffness, atherosclerotic burden and endothelial function. Nevertheless, the highest level of evidence, derived from well-designed randomised controlled trials (RCTs), has been inconsistent as to whether VitD exerts cardioprotective effects. In this short narrative review, we sought to summarise the observational data and critique evidence from published RCTs on the effect of VitD supplementation on cardiovascular surrogate and hard clinical end points, with particular consideration of study design (i.e., sample size, duration of supplementation, selection of VitD-deficient subjects, VitD dose and population under investigation).

\section{Summary of Observational Data on the Relationship between Serum VitD and Cardiovascular Outcomes}

\section{Cardiovascular Events and Cardiovascular Death}

Studies examining whether VitD is associated with cardiovascular events or cardiovascular death are seen in Figure 1. VitD deficiency has been associated with an increased risk of death, HF, MI or stroke in healthy postmenopausal women [10], as well as with an increased risk of sudden cardiac death or fatal or non-fatal stroke, non-fatal MI and death related to other heart diseases among diabetic patients with chronic kidney disease (CKD) [11]. In a small study of patients with acute coronary syndrome, VitD deficiency was also independently associated with in-hospital cardiovascular death [12]. In general population studies, low VitD levels were associated with an increased incidence of coronary artery disease, MI, HF, stroke and all-cause death [13], as well as increased cardiovascular death [14]. Several other studies have demonstrated an increased risk of cardiovascular death associated with low VitD levels among different patient groups including HF outpatients (in a small study) [15], patients with metabolic syndrome and cardiovascular symptoms [16], and patients with chronic obstructive pulmonary disease [17]. Furthermore, data extracted from medical records of 126 men with moderate CKD and VitD deficiency showed that VitD treatment was associated with decreased cardiovascular events [18]. In this study, the treatment group was defined based on an increase in serum VitD levels by $25 \%$ from baseline within 6 months, whilst the remaining patients were considered as controls. The risk of cardiovascular death was also lower among haemodialysis patients regularly using VitD supplements in a Japanese hospital (the VitD dose varied according to prescription) [19]. Overall, these data suggest fairly consistently that low VitD levels are associated with an increased risk of cardiovascular events, including death; in addition, the data hint towards the potential for VitD supplementation possibly reversing the adverse cardiovascular effects of low VitD. 
Veloudi et al.: Effectiveness of Vitamin D Supplementation for Cardiovascular Health Outcomes

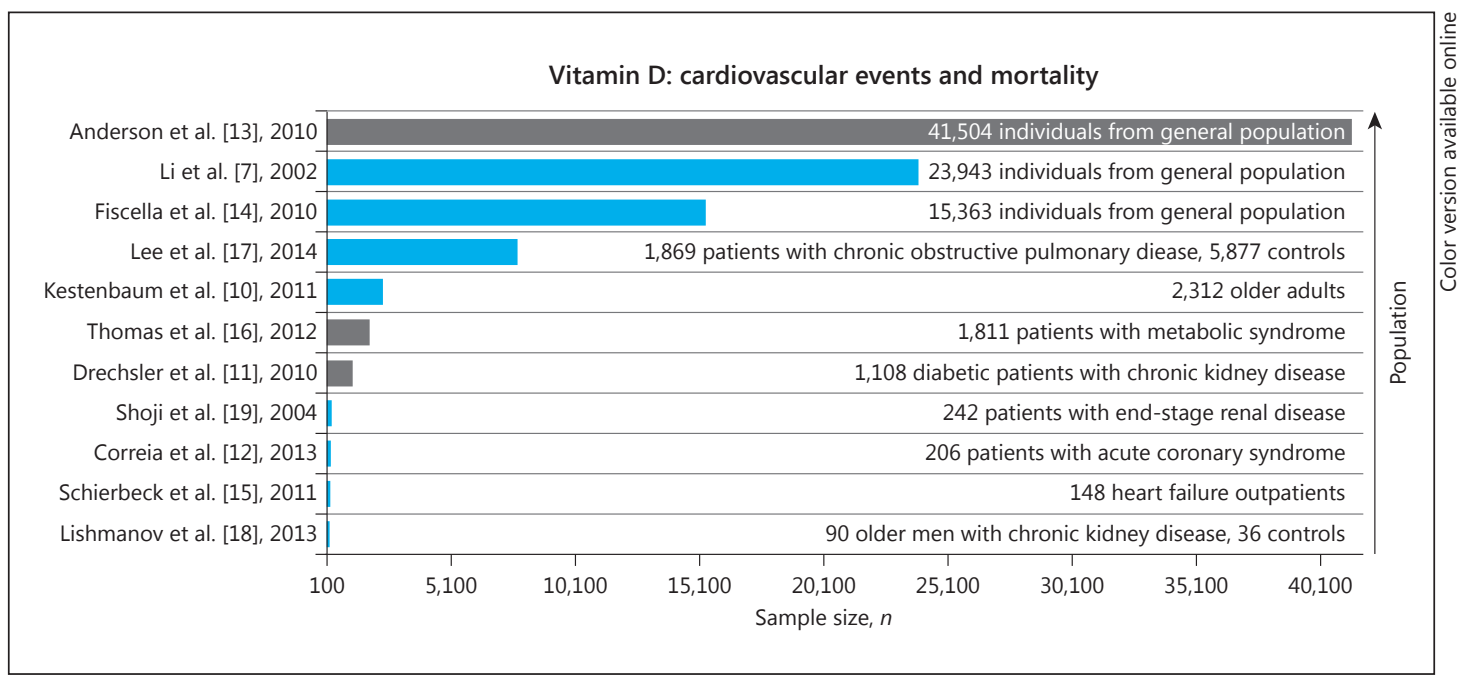

Fig. 1. Longitudinal cohort and case-control studies on the association between vitamin $D$ and incidence of cardiovascular events or cardiovascular mortality according to sample size and population characteristics. Blue bars indicate studies that reported significant associations between vitamin D and cardiovascular end points, and grey bars indicate studies that reported no significant associations. (Colours refer to the online version only.)

\section{$B P$ and Large Artery Stiffness}

Brachial BP, large artery stiffness (as measured by carotid-to-femoral pulse wave velocity [cfPWV], an estimate of aortic pulse wave velocity and the current "gold standard" measure of large artery stiffness) [20] and central hemodynamic parameters (such as augmentation index [AIX], a marker of central systolic loading) are independent predictors of cardiovascular risk [21,22]. Many observational studies have reported an inverse association between low VitD levels and brachial BP in large samples from the general population [23-25], but also among Peruvian adolescents [26], middle-aged individuals [27], people aged $>60$ years and the elderly [28, 29], pregnant women and women aged 20-80 years [30,31]. Similarly, the evidence from medium to large observational studies shows strong and independent inverse associations between serum VitD and cfPWV among diverse study populations [32-38]. Other markers of regional arterial stiffness, including increased carotid-radial pulse wave velocity and brachial-ankle pulse wave velocity, have been associated with lower VitD levels among people with type 2 diabetes mellitus (T2DM) [39, 40]. An inverse association between VitD levels and AIx has also been shown in pre-diabetic individuals and cardiac or kidney clinic outpatients $[41,42]$. In summary, observational evidence is consistently and strongly supportive of an association between VitD, BP and vascular health.

\section{Markers of Atherosclerotic Burden and Endothelial Function}

Strong relationships have also been observed between VitD level, atherosclerotic burden and endothelial function markers. Carotid intima medial thickness (CIMT), a marker of large artery atherosclerosis, known to be predictive of cardiovascular events [43], was found to be inversely associated with low VitD levels among different populations, including apparently healthy, predominantly white older individuals [44], relatively healthy Chinese women [45] and patients with peripheral arterial disease [46]. Additionally, endothelial flow-mediated dilation (FMD; the change in vessel diameter during reactive hyperaemia after cuff release), a marker of nitric oxide-mediated endothelial function, has been shown to be decreased in 
Veloudi et al.: Effectiveness of Vitamin D Supplementation for Cardiovascular Health Outcomes

the presence of low serum VitD levels in patients with T2DM [47], end-stage renal disease [48] and CKD [49]. Altogether, the above observational evidence points to the need for intervention trials to determine if there is a causative link between low VitD and poor cardiovascular health.

\section{Summary of RCT Data on the Effect of VitD Supplementation on Cardiovascular Diseases Outcomes}

\section{Cardiovascular Events and Cardiovascular Death, BP and Large Artery Stiffness}

A total of 45 RCTs on the effect of VitD supplementation on cardiovascular surrogate and hard clinical end points were identified through an English language search of PubMed and Google. To our knowledge, only 1 RCT has investigated the effects of VitD supplementation on hard clinical end points, which included incident MI, stroke and death related to coronary heart disease. This study randomised 36,282 postmenopausal women to 200 IU VitD plus calcium carbonate twice daily or placebo for 7 years and found that VitD supplementation did not improve cardiovascular risk [50]. Importantly, this study was criticised for using a low VitD dose and not measuring serum VitD levels [51, 52]. In terms of effects on BP, some RCTs have reported significant improvements in brachial BP after short-term supplementation of VitD among participants encompassing a variety of clinical characteristics, including patients with hypercalcaemia [53] or impaired glucose tolerance [54], patients with primary hyperparathyroidism [55], patients with T2DM [56-58], patients with elevated BP and VitD deficiency [59] and women with VitD deficiency [60]. However, the majority of RCTs have been ineffective in improving brachial BP in a range of populations as shown in Table 1 [61-79]. Indeed, a recent individual-level meta-analysis of RCTs concluded that VitD was ineffective in lowering BP [80].

Organ damage is more closely associated with central BP (cBP) than brachial BP [81] and, whilst individuals could have similar brachial systolic BP levels, central systolic BP may significantly differ [82]. Only 1 study has shown VitD supplementation to be effective in decreasing cBP (Table 1) [83], whereas others have shown no improvement in older individuals with osteoarthritis [77] or among postmenopausal women [61, 62]. VitD supplementation was also ineffective in changing visit-to-visit BP variability [77]. Central arterial stiffness is strongly associated with BP [9], and there is a need for interventions aimed at improving central arterial stiffness independent of BP changes. Virtually all RCTs investigating the effect of VitD supplementation on cfPWV reported no improvement $[61,64,70,71$, 77, 83-85] apart from 1 study in black youths [74]. The results from RCTs on AIx are more contradicting; no improvement was reported in the majority of studies $[61,62,64,71,72,77$, 83]. Alternatively, decreases in AIx were observed among patients with T2DM [66], overweight people with elevated BP [75], people with VitD deficiency [84] and those with prehypertension and VitD deficiency [85]. Conversely, 1 study reported significant increases in AIx in patients with T2DM and hypovitaminosis [63]. No improvements were reported in a small number of RCTs for carotid-radial PWV and brachial-ankle PWV [64, 65, 74, 75]. In summary, the majority of evidence from RCTs is not supportive of VitD treatment for improving BP control or large artery stiffness.

\section{Markers of Atherosclerotic Burden and Endothelial Function}

RCTs examining markers related to atherosclerotic burden as measured by CIMT are limited. No improvement in CIMT was reported among postmenopausal women; however, in this trial the supplementation regimen contained both VitD and vitamin $\mathrm{K}$ [86]. In terms of brachial FMD, improvements were reported among African Americans [87] and patients with 
Veloudi et al.: Effectiveness of Vitamin D Supplementation for Cardiovascular Health

Table 1. Effect of vitamin D supplementation on cardiovascular outcomes in randomised controlled trials in various populations

\begin{tabular}{|c|c|c|c|c|c|c|}
\hline $\begin{array}{l}\text { Study [ref.], } \\
\text { year }\end{array}$ & Population (group $n$ ) & $\begin{array}{l}\text { Vitamin D } \\
\text { level; in- } \\
\text { clusion cri- } \\
\text { teria, ng/mL }\end{array}$ & $\begin{array}{l}\text { Effect } \\
\text { on } \\
\text { brachial } \\
\mathrm{BP}^{\dagger}\end{array}$ & $\begin{array}{l}\text { Effect } \\
\text { on } \mathrm{cBP}^{\dagger}\end{array}$ & $\begin{array}{l}\text { Effect } \\
\text { on } \\
\text { cfPWV }^{\dagger}\end{array}$ & $\begin{array}{l}\text { Effect } \\
\text { on } \\
\mathrm{AIx}^{\dagger}\end{array}$ \\
\hline $\begin{array}{l}\text { Dalan et al. } \\
{[63], 2016}\end{array}$ & Individuals with T2DM and hypovitaminosis D (treatment $=33$, control $=31$ ) & $<30$ & Null & - & - & Increase \\
\hline $\begin{array}{l}\text { Zaleski et al. } \\
\text { [85], } 2015\end{array}$ & $\begin{array}{l}\text { Individuals with pre-hypertension and vitamin D deficiency (low dose }=22 \text {, } \\
\text { high dose }=19 \text { ) }\end{array}$ & $\leq 25^{*}$ & Null & - & Null & Decrease \\
\hline $\begin{array}{l}\text { Veloudi et al. } \\
{[77], 2015}\end{array}$ & $\begin{array}{l}\text { Older individuals with osteoarthritis and vitamin D deficiency } \\
\text { (intervention }=118, \text { control }=123 \text { ) }\end{array}$ & $<24^{*}$ & Null & Null & Null & Null \\
\hline $\begin{array}{l}\text { Pilz et al. } \\
{[92], 2015}\end{array}$ & Individuals with hypertension (intervention $=100$, control $=100$ ) & $<30$ & Null & - & & \\
\hline $\begin{array}{l}\text { McGreevey et al. } \\
{[84], 2015}\end{array}$ & Individuals with vitamin D deficiency (low dose $=60$, high dose $=50$ ) & $<20^{*}$ & - & & Null & Decrease \\
\hline $\begin{array}{l}\text { Gepner et al. } \\
{[62], 2015}\end{array}$ & $\begin{array}{l}\text { Healthy postmenopausal Native American women (low dose }=49 \text {, high } \\
\text { dose }=49 \text { ) }\end{array}$ & $<60$ & Null & Null & - & Null \\
\hline $\begin{array}{l}\text { Thethi et al. } \\
{[90], 2015}\end{array}$ & Individuals with T2DM and stage 3 or 4 CKD (treatment $=30$, control $=30$ ) & $\begin{array}{l}\text { No } \\
\text { restrictions }\end{array}$ & Null & - & - & - \\
\hline $\begin{array}{l}\text { Arora et al. } \\
{[94], 2015}\end{array}$ & $\begin{array}{l}\text { Individuals with pre-hypertension or stage } 1 \text { hypertension and low vitamin } \\
\text { status (low dose }=188 \text {, high dose }=175 \text { ) }\end{array}$ & $\leq 25^{*}$ & Null & - & - & - \\
\hline $\begin{array}{l}\text { Witham et al. } \\
\text { [95], } 2014\end{array}$ & $\begin{array}{l}\text { Patients aged }>70 \text { years with orthostatic hypotension (intervention }=38 \text {, } \\
\text { control }=37 \text { ) }\end{array}$ & $<30$ & Null & - & - & - \\
\hline $\begin{array}{l}\text { Witham et al. } \\
\text { [116], } 2014\end{array}$ & Patients with resistant hypertension (intervention $=31$, control $=30$ ) & $<30$ & Null & - & - & - \\
\hline $\begin{array}{l}\text { Scragg et al. } \\
\text { [68], } 2014\end{array}$ & Healthy adults (intervention $=161$, control $=161$ ) & $\begin{array}{l}\text { No } \\
\text { restrictions }\end{array}$ & Null & - & - & - \\
\hline $\begin{array}{l}\text { Ryu et al. } \\
{[64], 2014}\end{array}$ & Individuals with T2DM (intervention $=40$, control $=41$ ) & $<20^{*}$ & Null & - & Null & Null \\
\hline $\begin{array}{l}\text { Nasri et al. } \\
\text { [58], } 2014\end{array}$ & Individuals with T2DM (intervention $=30$, control $=30$ ) & $\begin{array}{l}\text { No } \\
\text { restrictions }\end{array}$ & Decrease & & - & - \\
\hline $\begin{array}{l}\text { Mozaffari- } \\
\text { Khosravi et al. } \\
\text { [59], } 2015\end{array}$ & $\begin{array}{l}\text { Patients with elevated BP and vitamin D deficiency (intervention = 19, } \\
\text { control }=20 \text { ) }\end{array}$ & $<30$ & Decrease & - & - & - \\
\hline $\begin{array}{l}\text { Martins et al. } \\
\text { [75], } 2014\end{array}$ & $\begin{array}{l}\text { Overweight and obese African Americans with elevated BP (intervention = } \\
65 \text {, control =65) }\end{array}$ & $10-25^{*}$ & - & - & - & Decrease \\
\hline $\begin{array}{l}\text { Dreyer et al. } \\
{[70], 2014}\end{array}$ & Patients with CKD (intervention $=20$, control $=18$ ) & $<16^{*}$ & Null & - & Null & - \\
\hline $\begin{array}{l}\text { Yiu et al. [65], } \\
2013\end{array}$ & Individuals with T2DM (intervention $=50$, control $=50$ ) & $<30$ & Null & - & - & - \\
\hline $\begin{array}{l}\text { Witham et al. } \\
\text { [96], } 2013\end{array}$ & Older patients with isolated hypertension (intervention $=80$, control $=79$ ) & $<30$ & Null & - & - & - \\
\hline $\begin{array}{l}\text { Witham et al. } \\
\text { [73], } 2013\end{array}$ & $\begin{array}{l}\text { Patients with a history of myocardial infarction (intervention }=39 \text {, control }= \\
36 \text { ) }\end{array}$ & $\begin{array}{l}\text { No } \\
\text { restrictions }\end{array}$ & Null & - & - & - \\
\hline $\begin{array}{l}\text { Forman et al. } \\
\text { [79], } 2013\end{array}$ & $\begin{array}{l}\text { Black individuals (intervention } 1,000 \mathrm{IU} / \text { day }=68 \text {, intervention } 2,000 \mathrm{IU} / \\
\text { day }=73 \text {, intervention } 4,000 \mathrm{IU} / \text { day }=70 \text {, control }=72 \text { ) }\end{array}$ & $\begin{array}{l}\text { No } \\
\text { restrictions }\end{array}$ & Decrease $^{\ddagger}$ & - & - & - \\
\hline $\begin{array}{l}\text { Breslavsky et al. } \\
{[66], 2013}\end{array}$ & Individuals with T2DM (intervention $=24$, control $=23$ ) & $\begin{array}{l}\text { No } \\
\text { restrictions }\end{array}$ & Null & - & - & Decrease \\
\hline $\begin{array}{l}\text { Marckmann et al. } \\
\text { [71], } 2012\end{array}$ & CKD patients with hypovitaminosis D (intervention $=25$, control $=24$ ) & $<20^{*}$ & Null & - & Null & Null \\
\hline $\begin{array}{l}\text { Stricker et al. } \\
{[72], 2012}\end{array}$ & Patients with peripheral arterial disease (intervention $=31$, control $=31$ ) & $<30$ & - & - & - & Null \\
\hline $\begin{array}{l}\text { Witham et al. } \\
\text { [69], } 2012\end{array}$ & Stroke patients with well-controlled BP (intervention $=30$, control $=28$ ) & $<30$ & Null & - & - & - \\
\hline $\begin{array}{l}\text { Gepner et al. } \\
\text { [61], } 2012\end{array}$ & Postmenopausal women (intervention $=55$, control $=54$ ) & $<60$ & Null & Null & Null & Null \\
\hline $\begin{array}{l}\text { Larsen et al. } \\
\text { [83], } 2012\end{array}$ & Individuals with hypertension (intervention $=55$, control $=57$ ) & $\begin{array}{l}\text { No } \\
\text { restrictions }\end{array}$ & Null & Decrease & Null & Null \\
\hline $\begin{array}{l}\text { Witham et al. } \\
\text { [57], } 2010\end{array}$ & $\begin{array}{l}\text { Individuals with T2DM (intervention 100,000 } \mathrm{IU}=19 \text {, intervention 200,000 } \\
\mathrm{IU}=20 \text {, control }=22 \text { ) }\end{array}$ & $<40$ & Decrease & - & - & - \\
\hline $\begin{array}{l}\text { Jorde et al. } \\
\text { [76], } 2010\end{array}$ & $\begin{array}{l}\text { Overweight and obese subjects (intervention 40,000 IU = 150, intervention } \\
10,000 \mathrm{IU}=139 \text {, control }=149 \text { ) }\end{array}$ & $\begin{array}{l}\text { No } \\
\text { restrictions }\end{array}$ & Increase & - & - & - \\
\hline $\begin{array}{l}\text { Dong et al. } \\
{[74], 2010}\end{array}$ & Black youth (intervention $=23$, control $=21$ ) & $\begin{array}{l}\text { No } \\
\text { restrictions }\end{array}$ & Null & - & Decrease & - \\
\hline $\begin{array}{l}\text { Daly et al. } \\
\text { [78], } 2009\end{array}$ & Men aged $>50$ years (intervention $=73$, control $=67$ ) & $\begin{array}{l}\text { No } \\
\text { restrictions }\end{array}$ & Null & - & - & - \\
\hline $\begin{array}{l}\text { Zittermann et al. } \\
\text { [97], } 2009\end{array}$ & $\begin{array}{l}\text { Healthy overweight subjects with inadequate vitamin D status } \\
\text { (intervention }=82, \text { control }=83 \text { ) }\end{array}$ & $\begin{array}{l}\text { No } \\
\text { restrictions }\end{array}$ & Null & - & - & - \\
\hline $\begin{array}{l}\text { Sugden et al. } \\
\text { [56], } 2008\end{array}$ & $\begin{array}{l}\text { Individuals with T2DM and low vitamin D levels (intervention }=17 \text {, control = } \\
\text { 17) }\end{array}$ & $<20^{*}$ & Decrease & - & - & - \\
\hline $\begin{array}{l}\text { Margolis et al. } \\
\text { [93], } 2008\end{array}$ & Postmenopausal women (intervention $=15,176$, control $=18,106$ ) & $\begin{array}{l}\text { No } \\
\text { restrictions }\end{array}$ & Null & - & - & - \\
\hline $\begin{array}{l}\text { Pfeifer et al. } \\
{[60], 2001}\end{array}$ & Women with vitamin D deficiency (intervention $=74$, control $=74$ ) & $<20^{*}$ & Decrease & - & - & - \\
\hline $\begin{array}{l}\text { Scragg et al. } \\
{[67], 1995}\end{array}$ & Healthy adults (intervention $=95$, control $=94$ ) & $\begin{array}{l}\text { No } \\
\text { restrictions }\end{array}$ & Null & - & - & - \\
\hline
\end{tabular}


Table 1 (continued)

\begin{tabular}{|c|c|c|c|c|c|c|}
\hline $\begin{array}{l}\text { Study [ref.], } \\
\text { year }\end{array}$ & Population (group $n$ ) & $\begin{array}{l}\text { Vitamin D } \\
\text { level; in- } \\
\text { clusion cri- } \\
\text { teria, ng/mL }\end{array}$ & $\begin{array}{l}\text { Effect } \\
\text { on } \\
\text { brachial } \\
\mathrm{BP}^{\dagger}\end{array}$ & $\begin{array}{l}\text { Effect } \\
\text { on } \mathrm{cBP}^{\dagger}\end{array}$ & $\begin{array}{l}\text { Effect } \\
\text { on } \\
\text { cfPWV }^{\dagger}\end{array}$ & $\begin{array}{l}\text { Effect } \\
\text { on } \\
\mathrm{AIx}^{\dagger}\end{array}$ \\
\hline $\begin{array}{l}\text { Pan et al. } \\
\text { [117], } 1993\end{array}$ & $\begin{array}{l}\text { Elderly individuals (intervention } \mathrm{Ca}=14 \text {, intervention vitamin } \mathrm{D}=14 \text {, } \\
\text { intervention } \mathrm{Ca}+\text { vitamin } \mathrm{D}=15 \text {, control }=15 \text { ) }\end{array}$ & $\begin{array}{l}\text { No } \\
\text { restrictions }\end{array}$ & Null & - & - & - \\
\hline $\begin{array}{l}\text { Orwoll et al. } \\
{[98], 1990}\end{array}$ & Normotensive men (intervention $=35$, control $=30$ ) & $\begin{array}{l}\text { No } \\
\text { restrictions }\end{array}$ & Null & - & - & - \\
\hline $\begin{array}{l}\text { Lind et al. } \\
{[118], 1989}\end{array}$ & Patients with essential hypertension $(n=39$, allocation not reported) & $\begin{array}{l}\text { No } \\
\text { restrictions }\end{array}$ & Null & - & - & - \\
\hline $\begin{array}{l}\text { Lind et al. } \\
\text { [55], } 1988\end{array}$ & Patients with primary hyperparathyroidism (intervention $=15$, control $=16$ ) & $\begin{array}{l}\text { No } \\
\text { restrictions }\end{array}$ & Decrease & - & - & - \\
\hline $\begin{array}{l}\text { Lind et al. } \\
\text { [54], } 1988\end{array}$ & Men with impaired glucose tolerance (intervention $=33$, control $=32$ ) & $\begin{array}{l}\text { No } \\
\text { restrictions }\end{array}$ & Decrease & - & - & - \\
\hline $\begin{array}{l}\text { Lind et al. } \\
{[53], 1987}\end{array}$ & $\begin{array}{l}\text { Patients with marginal, intermittent hypercalcaemia (intervention }=29 \text {, } \\
\text { control = 57) }\end{array}$ & $\begin{array}{l}\text { No } \\
\text { restrictions }\end{array}$ & Decrease & - & - & - \\
\hline
\end{tabular}

AIx, augmentation index; BP, blood pressure; cBP, central blood pressure; cfPWV, carotid-to-femoral pulse wave velocity; CKD, chronic kidney disease; T2DM, type 2 diabetes mellitus. * Vitamin D deficiency $(<25 \mathrm{ng} / \mathrm{mL}) .{ }^{\dagger}$ Statistically significant increase or decrease or no change (null) with vitamin $\mathrm{D}$ supplementation. * No longer statistically significant after adjustment for BP differences at baseline.

T2DM [56], whilst brachial FMD was improved after 8 weeks in stroke patients, but this did not persist at 16 weeks [69]. No improvements in brachial FMD were observed among patients with coronary artery disease [88], patients with T2DM [57, 65], HIV-infected individuals [89] and postmenopausal women $[61,90]$. Lastly, VitD was found to have no effect on the reactive hyphaemia index in patients with T2DM or after MI $[63,73]$. Based on current evidence, VitD supplementation appears to be ineffective in improving CIMT or FMD.

\section{Critical Factors to Consider Regarding the Interpretation of RCT Data}

\section{Adequate Sample Size}

Sample size should be adequate to determine a clinically relevant change from intervention, and this will vary depending on outcomes. With respect to $\mathrm{BP}$, we have calculated that at least 100 participants in each randomisation arm are needed to detect at least $4.5 \mathrm{~mm}$ $\mathrm{Hg}$ between-group change in brachial BP or CBP [91]. Figure 2 depicts RCTs in relation to their sample size and effectiveness of VitD treatment for cardiovascular end points. Generally, most of the effective trials were of a smaller sample size. Seven RCTs with an apparently appropriate sample size have investigated the effects of VitD on brachial BP, and from these, 6 reported no significant improvement [68, 76, 77, 92-94]. Only 1 trial reported significant BP lowering, and this was in a population of black individuals [79]; importantly though, this effect was no longer significant after correcting for between-group differences in BP at baseline. We recently published the largest RCT investigating changes in cBP, cfPWV and AIx, which found no significant effects of VitD (Fig. 2) [77]. Overall, Figure 2 shows that in the larger RCTs with a sample size $>200$, VitD has been ineffective in improving cardiovascular surrogate markers.

\section{Adequate Length of Intervention Period}

The generalizability of RCT findings must be interpreted in the context of the duration of intervention, given that a short-term RCT may produce results discordant with long-term effects. Although there is no consensus as to the minimum duration of VitD intervention for maximum improvements in $\mathrm{BP}$, interventions of $<6$ months may not be adequate to modify the structural characteristics of the large arteries (i.e., improving arterial stiffness independent of BP). The majority of the RCTs included in this review had a duration of $\leq 6$ months 
Veloudi et al.: Effectiveness of Vitamin D Supplementation for Cardiovascular Health Outcomes

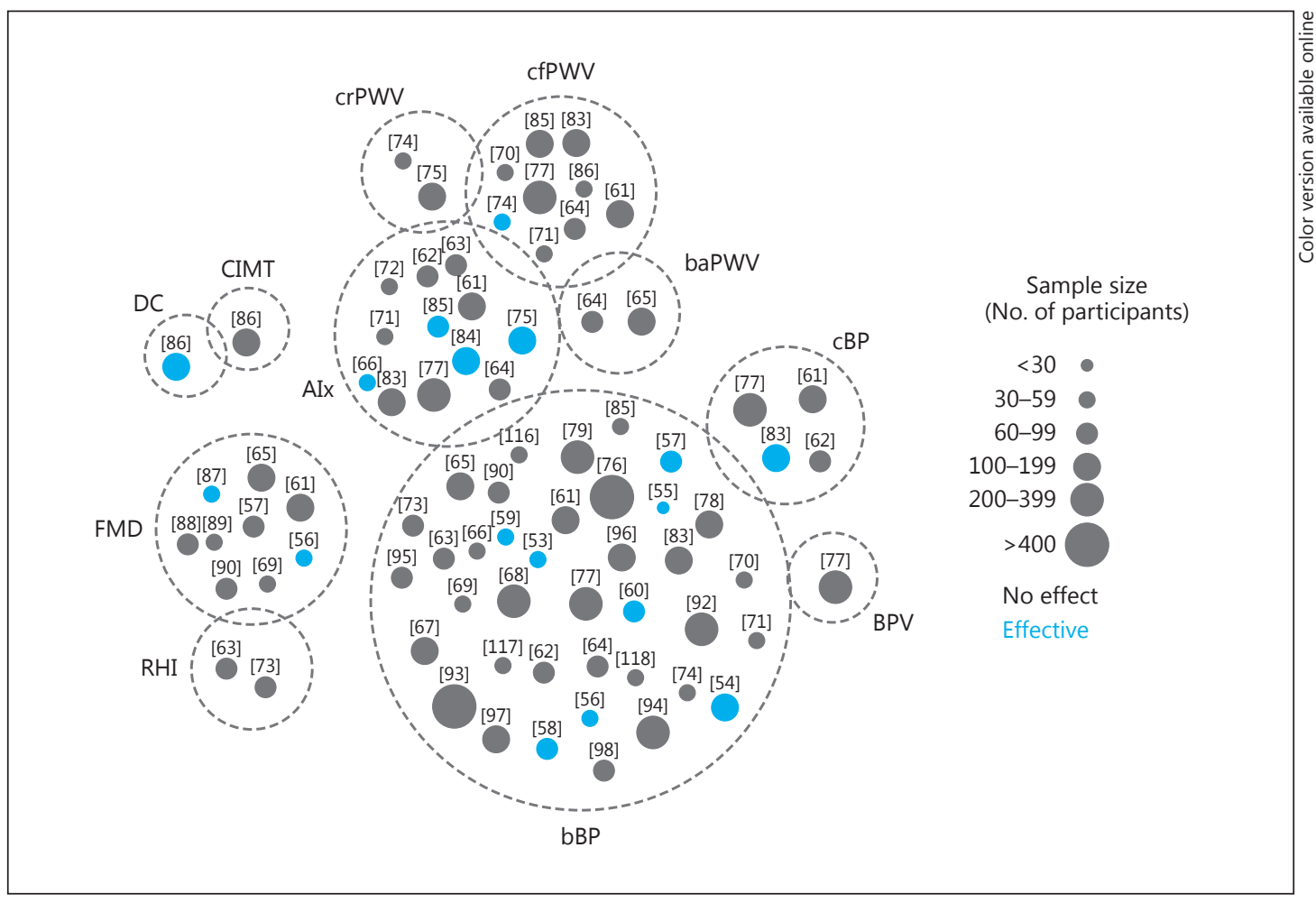

Fig. 2. Randomised controlled trials (RCTs) with vitamin D supplementation as the intervention according to sample size and the outcome in terms of effective or no effect on cardiovascular end points (reported either as primary or secondary outcomes). Each grey dotted circle represents a different cardiovascular end point, and the size of the circle is proportional to the number of RCTs for each end point. Blue circles indicate a significant improvement with vitamin D supplementation (effective RCTs), and grey circles indicate that RCTs had no significant effect on respective end points. Numbers above the circles represent the corresponding RCT reference number. bBP, brachial blood pressure; RHI, reactive hyperaemia index; FMD, flow-mediated dilation; DC, distensibility coefficient of the carotid artery; CIMT, carotid intimal medial thickness; AIx, augmentation index; crPWV, carotid-radial pulse wave velocity; cfPWV, carotid-femoral pulse wave velocity; baPWV, brachial-ankle pulse wave velocity; cBP, central blood pressure; BPV, visit-to-visit blood pressure variability. (Colours refer to the online version only.)

(76\%), whilst approximately half of these short-term RCTs had a duration of $\leq 3$ months. Figure 3 shows RCTs according to trial duration and effect of estimated monthly dose on brachial BP and cfPWV. Only 10 RCTs examining the effects of treatment on brachial BP had a duration $\geq 12$ months. Importantly, none of these longer-term RCTs observed an improvement in brachial BP with VitD supplementation [66, 68, 76-78, 93, 95-98]. Additionally, the only longer-term (1 year) RCT investigating the effects of VitD on cfPWV was ineffectual [77]. Although Breslavsky et al. [66] showed an improvement in AIx after 1 year of supplementation among patients with T2DM, this was a small study $(n=47)$. Lastly, a longterm RCT (3 years) among postmenopausal women, with CIMT as the outcome, found no significant effects [86]. When RCT duration is taken into account, it is clear that intervention durations $>6$ months have been ineffective in improving cardiovascular outcomes.

Baseline VitD Level

A series of rules regarding optimal design of RCTs examining nutrient effects has recently been introduced [99]. Rule 1 states that individuals with low baseline nutrient levels should 
Veloudi et al.: Effectiveness of Vitamin D Supplementation for Cardiovascular Health Outcomes

be recruited. This is based on the pharmacological dose-response curve of nutrient intake; if baseline nutrient levels are deficient, then an increase in these levels is expected to produce a clinically meaningful and measurable effect on outcomes, whereas if baseline levels are within optimal ranges, then a further increase will produce no significant effects. Conversely, if baseline levels are high, then intervention could cause adverse effects due to toxicity. Overall, among the 45 RCTs included in this review, only 27\% $(n=12)$ included patients with VitD deficiency (defined as $<25 \mathrm{ng} / \mathrm{ml}$; according to Mayo Medical Laboratories reference ranges) [100]. The remaining $73 \%$ of studies placed no restrictions on baseline serum VitD levels or included a combination of deficient and non-deficient participants (i.e., $<30,<40$ or $<60 \mathrm{ng} / \mathrm{ml}$ ), which could confound the results. Among the RCTs that included VitD-deficient participants and investigated the effects on brachial BP $(n=8), 6$ had no significant effects $[64,70,71,77,85,94]$ and 2 (very short-term; $\leq 3$ months) trials reported an improvement in brachial BP $[56,60]$ (Table 1). None of the RCTs appropriately addressing rule 1 found a significant effect on cfPWV [64, 70, 71, 77, 84, 85], carotid-radial PWV [75] or brachial-ankle PWV [64]. With respect to AIx, among the trials that have recruited VitD-deficient participants, 2 short-term RCTs showed an improvement [75, 84], 2 RCTs with longer duration failed to find significant effects [64, 77] and 1 RCT reported a paradoxical increase in AIx among individuals with T2DM [63]. FMD was improved in 1 RCT, 8 weeks after a single oral VitD dose [56], but was not improved in 2 RCTs meeting rule 1 [88, 89]. In brief, VitD interventions that have recruited VitD-deficient participants generally failed to show significant treatment effects.

\section{Adequate VitD Dose}

Rules 2 and 3 of Heaney [99] require that the intervention dosage should be sufficient to change nutrient status (from deficient levels at baseline to sufficient levels at follow-up) and that the change in nutrient status must be reported. All $(n=12)$ but 1 RCT [85] that recruited VitD-deficient subjects were effective in increasing average VitD levels above deficiency, and all these RCTs reported the changes in serum VitD levels. In order to change baseline VitD levels from being deficient at baseline to being sufficient at follow-up, the dose of VitD should be adequate to raise serum VitD. Supplementation of 1,000-2,000 IU or lower, taken once or twice weekly (which translates to approximately 8,000-16,000 IU/month), has been shown to be insufficient for raising plasma 25-hydroxyvitamin D levels (the most objective biomarker for VitD nutritional adequacy [101]) higher than those of individuals who are not taking VitD supplements [102]. It is recommended that the VitD dose should be at least 50,000 IU/month in order to successfully raise baseline (deficient) serum VitD levels above $30 \mathrm{ng} / \mathrm{mL}(75$ $\mathrm{nmol} / \mathrm{L}$; the lowest sufficient threshold) [103]. Importantly, these recommendations are based on expectations for improving skeletal health outcomes and may not be relevant to cardiovascular related outcomes. Nonetheless, Figure 3 shows clearly that irrespective of the dose, the majority of RCTs failed to improve brachial BP or cfPWV.

Fig. 3. Randomised controlled trials (RCTs) on the effect of vitamin D supplementation according to trial duration and estimated monthly dose on brachial blood pressure and carotid-femoral pulse wave velocity. Blue bars indicate effective RCTs (significant reduction in end points), and grey bars indicate RCTs that had no effect on end points. Black dotted horizontal lines indicate adequate dose to raise serum vitamin D levels above deficiency levels. Black dotted vertical line indicates RCT duration of 6 months. Monthly dose was calculated using the highest dose if there was more than 1 vitamin D supplementation group. IU, international units. * Vitamin $\mathrm{D}_{2}$ supplementation. ${ }^{\dagger}$ Vitamin D plus calcium. ${ }^{\ddagger}$ Single dose. ${ }^{\S}$ Vitamin D/calcium-fortified milk. (Colours refer to the online version only.)

(For figure see next page.) 
Veloudi et al.: Effectiveness of Vitamin D Supplementation for Cardiovascular Health Outcomes

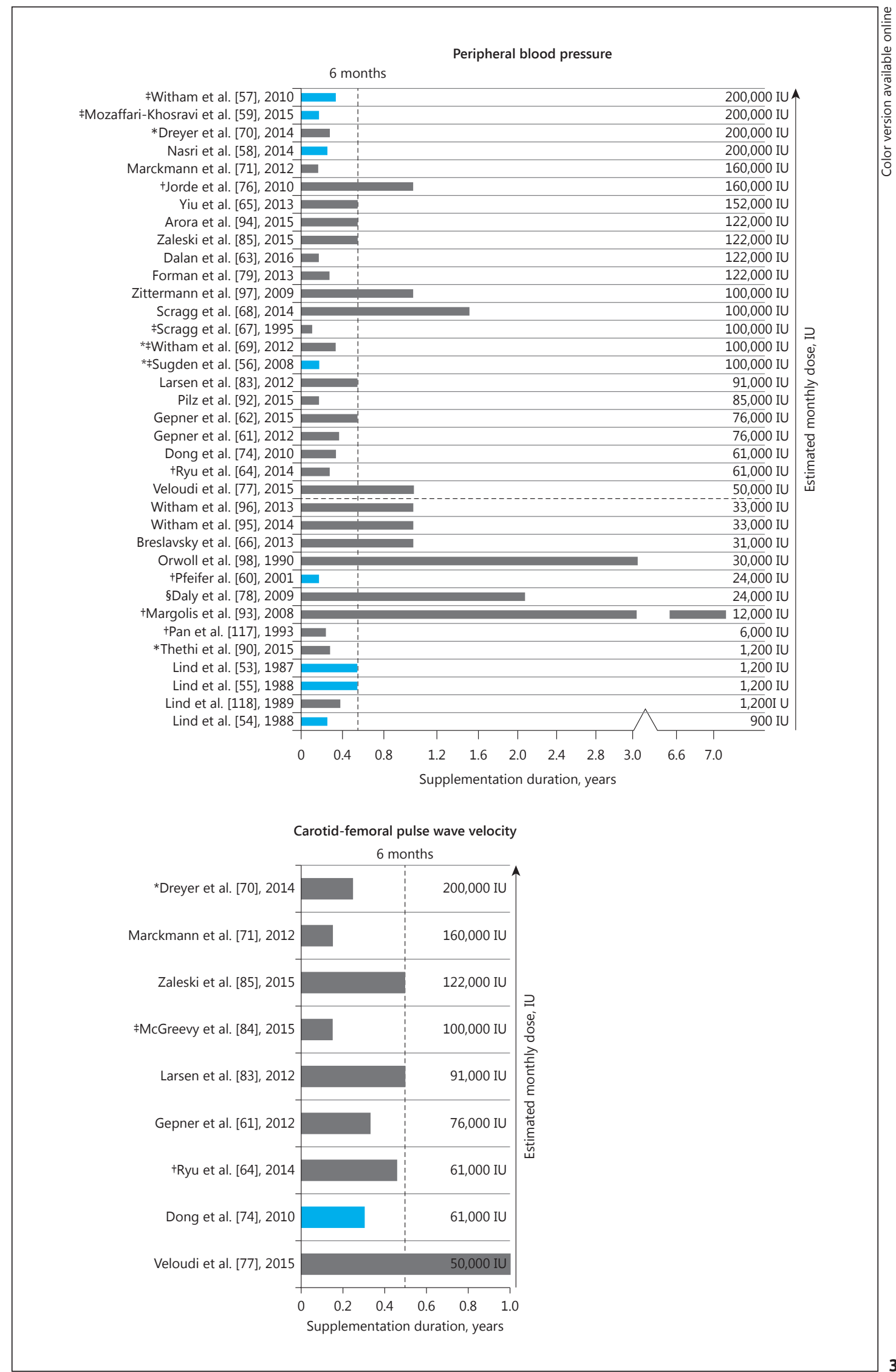


Rule 4 aims to ensure that the effect of a trial is a result of the change in the nutrient from the study intervention rather than a change in the diet. Although all 12 RCTs that met rules 1-3 reported changes in serum VitD levels, they did not state whether other steps were employed in order to monitor and adjust for issues related to adherence, such as variations in individual VitD absorption, changes in diet or other conditions that may have affected the change in serum VitD levels (i.e., physical activity, obesity or amount of exposure to sunlight $[104,105])$. Rule 5 considers confounding effects induced by changes in co-nutrient levels known to affect the outcomes (i.e., changes in serum calcium levels are monitored so that results are not biased by confounding effects). Among RCTs meeting rule 1-3, 7 studies monitored calcium and phosphorous levels but did not adjust the final results for the changes in calcium levels. None of the RCTs meeting rules 1-3 adjusted the final outcomes for changes in these factors. Thus, it cannot be excluded that the results from RCTs that met rules 1-3 may have been confounded by significant uncontrolled factors influencing nutrient status.

\section{High-Risk Populations}

The interpretation of RCTs may also be complicated by the selection of individuals without a high-risk profile in terms of cardiovascular disease or VitD deficiency. Table 1 shows the effect of VitD interventions on brachial and cBP, cfPWV and AIx in various populations. It can be seen that VitD is ineffective in improving cardiovascular health, irrespective of the population risk profile. Further examination among those RCTs meeting rules 1-3 as per Heaney [99] shows that VitD supplementation is ineffective in VitD-deficient individuals with pre-hypertension, hypertension, T2DM or CKD. Our own work found that VitD supplementation was not beneficial among older individuals with VitD deficiency and osteoarthritis, a condition associated with increased cardiovascular risk [106] and a population enriched with vascular risk factors that should be most amenable to benefit from treatment.

\section{Systematic Reviews and Meta-Analyses}

Several systematic reviews concluded that VitD supplementation does not have a significant effect on systolic BP (included RCTs: $n=46$ [80]; $n=8$ [107]; $n=10$ [108]; $n=16$ [109]), whilst a small meta-analysis of 4 RCTs showed evidence of a statistically significant effect on systolic BP [110], and others showed a statistically significant effect on diastolic BP (included RCTs: $n=8$ [107]; $n=15$ [111]; $n=16$ [112]). At the same time, recent systematic reviews and meta-analyses concluded that VitD has no effect on markers of arterial stiffness (included RCTs: $n=7$ [113]; $n=13$ [114]) or markers of endothelial function (included RCTs: $n=16$ [112]). In alignment with this narrative review, almost all of the published systematic reviews highlight the significant methodological heterogeneity in terms of dose and duration of treatment, which limits the interpretation of the findings and raises the need for a critical appraisal, over and beyond the reported results. Although some systematic reviews have used criteria to establish the quality of study design (i.e., allocation concealment, blinding, baseline comparability of groups, description of dropouts and intention-to-treat analysis), none of them have pooled the data according to the guidelines by Heaney [99]. Nevertheless, sensitivity analyses among the above analyses looking separately at either the effect of dose or duration of supplementation or baseline VitD status did not alter the null-effect findings $[80,112,114]$. 
Veloudi et al.: Effectiveness of Vitamin D Supplementation for Cardiovascular Health Outcomes

\section{Conclusions}

In summary, after consideration of the discrepancies in the study design of RCTs (i.e., sample size, duration of supplementation, selection of VitD-deficient subjects, VitD dose and population under investigation), VitD supplementation appears to be ineffective in improving brachial BP, large artery stiffness or central haemodynamics. This conclusion, though, cannot be generalised to other forms of contributions to endogenous VitD. The lack of evidence from large-scale RCTs with a priori primary measures of cardiovascular disease does not exclude the possibility of small but yet clinically meaningful VitD effects. Several large-scale RCTs in general populations ( $n>18,000$; duration of 5 years) are underway and should provide a more definite answer to this question [115]. Despite a lack of large and long-term studies investigating atherosclerotic burden and endothelial function markers, evidence from RCTs also contradicts observational data that support a role of VitD in improving these markers. Thus, this review supports the notion that the inverse associations seen in observational studies between low VitD levels and cardiovascular end points are likely to be epiphenomena rather than true cause-and-effect relationships.

\section{Disclosure Statement}

The authors declare that they have no conflicts of interest.

\section{References}

1 Gunton JE, Girgis CM, Baldock PA, Lips P: Bone muscle interactions and vitamin D. Bone 2015;80:89-94.

2 Tetlow LC, Woolley DE: Expression of vitamin D receptors and matrix metalloproteinases in osteoarthritic cartilage and human articular chondrocytes in vitro. Osteoarthr Cartilage 2001;9:423-431.

3 Norman PE, Powell JT: Vitamin D and cardiovascular disease. Circ Res 2014;114:379-393.

4 Rahman A, Hershey S, Ahmed S, Nibbelink K, Simpson RU: Heart extracellular matrix gene expression profile in the vitamin D receptor knockout mice. J Steroid Biochem Mol Biol 2007;103:416-419.

5 Wu-Wong JR, Nakane M, Ma J: Vitamin D analogs modulate the expression of plasminogen activator inhibitor-1, thrombospondin-1 and thrombomodulin in human aortic smooth muscle cells. J Vasc Res 2007;44:11-18.

6 Eelen G, Verlinden L, Laureys J, Marcelis S, De Clercq P, Mathieu C, et al: Antiproliferative and calcemic actions of trans-decalin CD-ring analogs of 1,25-dihydroxyvitamin D3. Anticancer Res 2009;29:3579-3584.

7 Li YC, Kong J, Wei M, Chen ZF, Liu SQ, Cao LP: 1,25-Dihydroxyvitamin D(3) is a negative endocrine regulator of the renin-angiotensin system. J Clin Invest 2002;110:229-238.

8 Yuan W, Pan W, Kong J, Zheng W, Szeto FL, Wong KE, et al: 1,25-Dihydroxyvitamin D3 suppresses renin gene transcription by blocking the activity of the cyclic AMP response element in the renin gene promoter. J Biol Chem 2007;282:29821-29830.

9 Cecelja M, Chowienczyk P: Dissociation of aortic pulse wave velocity with risk factors for cardiovascular disease other than hypertension: a systematic review. Hypertension 2009;54:1328-1336.

10 Kestenbaum B, Katz R, de Boer I, Hoofnagle A, Sarnak MJ, Shlipak MG, et al: Vitamin D, parathyroid hormone, and cardiovascular events among older adults. J Am Coll Cardiol 2011;58:1433-1441.

11 Drechsler C, Pilz S, Obermayer-Pietsch B, Verduijn M, Tomaschitz A, Krane V, et al: Vitamin D deficiency is associated with sudden cardiac death, combined cardiovascular events, and mortality in haemodialysis patients. Eur Heart J 2010;31:2253-2261.

12 Correia LC, Sodre F, Garcia G, Sabino M, Brito M, Kalil F, et al: Relation of severe deficiency of vitamin D to cardiovascular mortality during acute coronary syndromes. Am J Cardiol 2013;111:324-327.

13 Anderson JL, May HT, Horne BD, Bair TL, Hall NL, Carlquist JF, et al: Relation of vitamin D deficiency to cardiovascular risk factors, disease status, and incident events in a general healthcare population. Am J Cardiol 2010; 106:963-968.

14 Fiscella K, Franks P: Vitamin D, race, and cardiovascular mortality: findings from a national US sample. Ann Fam Med 2010;8:11-18.

15 Schierbeck LL, Jensen TS, Bang U, Jensen G, Kober L, Jensen JE: Parathyroid hormone and vitamin D - markers for cardiovascular and all cause mortality in heart failure. Eur J Heart Fail 2011;13:626-632.

16 Thomas GN, ó Hartaigh B, Bosch JA, Pilz S, Loerbroks A, Kleber ME, et al: Vitamin D levels predict all-cause and cardiovascular disease mortality in subjects with the metabolic syndrome: the Ludwigshafen Risk and Cardiovascular Health (LURIC) Study. Diabetes Care 2012;35:1158-1164. 
Veloudi et al.: Effectiveness of Vitamin D Supplementation for Cardiovascular Health Outcomes

17 Lee HM, Liu M, Lee K, Luo Y, Wong ND: Does low vitamin D amplify the association of COPD with total and cardiovascular disease mortality? Clin Cardiol 2014;37:473-478.

18 Lishmanov A, Dorairajan S, Pak Y, Chaudhary K, Chockalingam A: Treatment of 25-OH vitamin D deficiency in older men with chronic kidney disease stages 3 and 4 is associated with reduction in cardiovascular events. Am J Ther 2013;20:480-486.

19 Shoji T, Shinohara K, Kimoto E, Emoto M, Tahara H, Koyama H, et al: Lower risk for cardiovascular mortality in oral 1 $\alpha$-hydroxy vitamin D3 users in a haemodialysis population. Nephrol Dial Transplant 2004;19:179184.

20 Laurent S, Cockcroft J, Van Bortel L, Boutouyrie P, Giannattasio C, Hayoz D, et al: Expert consensus document on arterial stiffness: methodological issues and clinical applications. Eur Heart J 2006;27:2588-2605.

21 Ezzati M, Lopez AD, Rodgers A, Vander Hoorn S, Murray CJ; Comparative Risk Assessment Collaborating Group: Selected major risk factors and global and regional burden of disease. Lancet 2002;360:1347-1360.

22 Vlachopoulos C, Aznaouridis K, Stefanadis C: Prediction of cardiovascular events and all-cause mortality with arterial stiffness: a systematic review and meta-analysis. J Am Coll Cardiol 2010;55:1318-1327.

23 Judd SE, Nanes MS, Ziegler TR, Wilson PW, Tangpricha V: Optimal vitamin D status attenuates the age-associated increase in systolic blood pressure in white Americans: results from the third National Health and Nutrition Examination Survey. Am J Clin Nutr 2008;87:136-141.

24 Scragg R, Sowers M, Bell C: Serum 25-hydroxyvitamin D, ethnicity, and blood pressure in the Third National Health and Nutrition Examination Survey. Am J Hypertens 2007;20:713-719.

25 Zhao G, Ford ES, Li C, Kris-Etherton PM, Etherton TD, Balluz LS: Independent associations of serum concentrations of 25-hydroxyvitamin D and parathyroid hormone with blood pressure among US adults. J Hypertens 2010;28:1821-1828.

26 Tomaino K, Romero KM, Robinson CL, Baumann LM, Hansel NN, Pollard SL, et al: Association between serum 25-hydroxy vitamin D levels and blood pressure among adolescents in two resource-limited settings in Peru. Am J Hypertens 2015;28:1017-1023.

27 Lind L, Hanni A, Lithell H, Hvarfner A, Sorensen OH, Ljunghall S: Vitamin-D is related to blood-pressure and other cardiovascular risk-factors in middle-aged men. Am J Hypertens 1995;8:894-901.

28 Park HY, Kim JH, Bae S, Choi YY, Park JY, Hong YC: Interaction effect of serum 25-hydroxyvitamin D levels and CYP1A1, CYP1B1 polymorphisms on blood pressure in an elderly population. J Hypertens 2015;33:69-76.

29 Almirall J, Vaqueiro M, Bare ML, Anton E: Association of low serum 25-hydroxyvitamin D levels and high arterial blood pressure in the elderly. Nephrol Dial Transplant 2010;25:503-509.

30 Weinert LS, Reichelt AJ, Schmitt LR, Boff R, Oppermann ML, Camargo JL, Silveiro SP: Serum vitamin D insufficiency is related to blood pressure in diabetic pregnancy. Am J Hypertens 2014;27:1316-1320.

31 Sowers MFR, Wallace RB, Hollis BW, Lemke JH: Relationship between 1,25-dihydroxyvitamin-D and bloodpressure in a geographically defined population. Am J Clin Nutr 1988;48:1053-1056.

32 Mayer O, Filipovsky J, Seidlerova J, Vanek J, Dolejsova M, Vrzalova J, Cifkova R: The association between low 25-hydroxyvitamin D and increased aortic stiffness. J Hum Hypertens 2012;26:650-655.

33 Seker T, Gur M, Kuloglu O, Kalkan GY, Sahin DY, Turkoglu C, et al: Serum 25-hydroxyvitamin D is associated with both arterial and ventricular stiffness in healthy subjects. J Cardiol 2013;62:361-365.

34 Giallauria F, Milaneschi Y, Tanaka T, Maggio M, Canepa M, Elango P, et al: Arterial stiffness and vitamin D levels: the Baltimore Longitudinal Study of Aging. J Clin Endocr Metab 2012;97:3717-3723.

35 Rezai MR, Anderson SG, Sattar N, Finn J, Wu F, Cruickshank JK: Ethnic differences in aortic pulse wave velocity occur in the descending aorta independent of blood pressure and may be related to vitamin D. Hypertension 2011;25:632-633

36 Chang J, Ye XG, Hou YP, Wu JL, Li SL, Sun QM: Vitamin D level is associated with increased left ventricular mass and arterial stiffness in older patients with impaired renal function. Med Sci Monit 2015;21:3993-3999.

37 Kutlay S, Atli T, Aydogan I, Tutkak H, Nergizoglu G: The association of serum vitamin D levels with several cardiometabolic risk and aortic pulse wave velocity in elderly persons. Eur Geriatr Med 2014;5:238-241.

38 van Dijk SC, Sohl E, Oudshoorn C, Enneman AW, Ham AC, Swart KM, et al: Non-linear associations between serum 25-OH vitamin D and indices of arterial stiffness and arteriosclerosis in an older population. Age Ageing 2015;44:136-142.

39 Lee JI, Oh SJ, Ha WC, Kwon HS, Sohn TS, Son HS, Cha BY: Serum 25-hydroxyvitamin D concentration and arterial stiffness among type 2 diabetes. Diabetes Res Clin Pract 2012;95:42-47.

40 Jha P, Dolan LM, Khoury PR, Urbina EM, Kimball TR, Shah AS: Low serum vitamin D levels are associated with increased arterial stiffness in youth with type 2 diabetes. Diabetes Care 2015;38:1551-1557.

41 Zagami RM, Di Pino A, Urbano F, Piro S, Purrello F, Rabuazzo AM: Low circulating vitamin D levels are associated with increased arterial stiffness in prediabetic subjects identified according to HbA1c. Atherosclerosis 2015;243:395-401.

42 Andrade J, Er L, Ignaszewski A, Levin A: Exploration of association of 1,25-OH2D3 with augmentation index, a composite measure of arterial stiffness. Clin J Am Soc Nephrol 2008;3:1800-1806.

43 Bots ML, Hoes AW, Koudstaal PJ, Hofman A, Grobbee DE: Common carotid intima-media thickness and risk of stroke and myocardial infarction: the Rotterdam Study. Circulation 1997;96:1432-1437.

44 Reis JP, von Muhlen D, Michos ED, Miller ER 3rd, Appel LJ, Araneta MR, Barrett-Connor E: Serum vitamin D, parathyroid hormone levels, and carotid atherosclerosis. Atherosclerosis 2009;207:585-590. 
Veloudi et al.: Effectiveness of Vitamin D Supplementation for Cardiovascular Health Outcomes

45 Hao Y, Ma X, Luo Y, Xu Y, Xiong Q, Zhu J, et al: Inverse association of serum vitamin D in relation to carotid intima-media thickness in Chinese postmenopausal women. PLoS One 2015;10:e0122803.

46 van de Luijtgaarden KM, Voute MT, Hoeks SE, Bakker EJ, Chonchol M, Stolker RJ, et al: Vitamin D deficiency may be an independent risk factor for arterial disease. Eur J Vasc Endovasc Surg 2012;44:301-306.

47 Yiu YF, Chan YH, Yiu KH, Siu CW, Li SW, Wong LY, et al: Vitamin D deficiency is associated with depletion of circulating endothelial progenitor cells and endothelial dysfunction in patients with type 2 diabetes. J Clin Endocr Metab 2011;96:E830-E835.

48 London GM, Guerin AP, Verbeke FH, Pannier B, Boutouyrie P, Marchais SJ, Metivier F: Mineral metabolism and arterial functions in end-stage renal disease: potential role of 25-hydroxyvitamin D deficiency. J Am Soc Nephrol 2007;18:613-620.

49 Chitalia N, Recio-Mayoral A, Kaski JC, Banerjee D: Vitamin D deficiency and endothelial dysfunction in nondialysis chronic kidney disease patients. Atherosclerosis 2012;220:265-268.

50 Hsia J, Heiss G, Ren H, Allison M, Dolan NC, Greenland P, et al: Calcium/vitamin D supplementation and cardiovascular events. Circulation 2007;115:846-854.

51 Wallis DE, Penckofer S: Letter by Wallis and Penckofer regarding article, "Calcium/vitamin D supplementation and cardiovascular events." Circulation 2007;116:e86; author reply e87.

52 Zittermann A, Schleithoff SS, Koerfer R: Letter by Zitterman et al regarding article, "Calcium/vitamin D supplementation and cardiovascular events." Circulation 2007;116:e85; author reply e87.

53 Lind L, Wengle B, Ljunghall S: Blood-pressure is lowered by vitamin-D (alphacalcidol) during long-term treatment of patients with intermittent hypercalcemia - a double-blind, placebo-controlled study. Acta Med Scand 1987;222:423-427.

54 Lind L, Lithell H, Skarfors E, Wide L, Ljunghall S: Reduction of blood pressure by treatment with alphacalcidol. A double-blind, placebo-controlled study in subjects with impaired glucose tolerance. Acta Med Scand 1988; 223:211-217.

55 Lind L, Wengle B, Wide L, Sorensen OH, Ljunghall S: Hypertension in primary hyperparathyroidism - reduction of blood pressure by long-term treatment with vitamin D (alphacalcidol). A double-blind, placebo-controlled study. Am J Hypertens 1988;1:397-402.

56 Sugden JA, Davies JI, Witham MD, Morris AD, Struthers AD: Vitamin D improves endothelial function in patients with type 2 diabetes mellitus and low vitamin D levels. Diabet Med 2008;25:320-325.

57 Witham MD, Dove FJ, Dryburgh M, Sugden JA, Morris AD, Struthers AD: The effect of different doses of vitamin $\mathrm{D}(3)$ on markers of vascular health in patients with type 2 diabetes: a randomised controlled trial. Diabetologia 2010;53:2112-2119.

58 Nasri H, Behradmanesh S, Ahmadi A, Rafieian-Kopaei M: Impact of oral vitamin D (cholecalciferol) replacement therapy on blood pressure in type 2 diabetes patients; a randomized, double-blind, placebo controlled clinical trial. J Nephropathol 2014;3:29-33.

59 Mozaffari-Khosravi H, Loloei S, Mirjalili MR, Barzegar K: The effect of vitamin D supplementation on blood pressure in patients with elevated blood pressure and vitamin D deficiency: a randomized, double-blind, placebo-controlled trial. Blood Press Monit 2015;20:83-91.

60 Pfeifer M, Begerow B, Minne HW, Nachtigall D, Hansen C: Effects of a short-term vitamin D(3) and calcium supplementation on blood pressure and parathyroid hormone levels in elderly women. J Clin Endocrinol Metab 2001;86:1633-1637.

61 Gepner AD, Ramamurthy R, Krueger DC, Korcarz CE, Binkley N, Stein JH: A prospective randomized controlled trial of the effects of vitamin D supplementation on cardiovascular disease risk. PLoS One 2012; 7:e36617.

62 Gepner AD, Haller IV, Krueger DC, Korcarz CE, Binkley N, Stein JH: A randomized controlled trial of the effects of vitamin D supplementation on arterial stiffness and aortic blood pressure in Native American women. Atherosclerosis 2015;240:526-528.

63 Dalan R, Liew H, Assam PN, Chan ES, Siddiqui FJ, Tan AW, et al: A randomised controlled trial evaluating the impact of targeted vitamin D supplementation on endothelial function in type 2 diabetes mellitus: the DIMENSION trial. Diab Vasc Dis Res 2016;13:192-200.

64 Ryu OH, Chung W, Lee S, Hong KS, Choi MG, Yoo HJ: The effect of high-dose vitamin D supplementation on insulin resistance and arterial stiffness in patients with type 2 diabetes. Korean J Intern Med 2014;29:620629.

65 Yiu YF, Yiu KH, Siu CW, Chan YH, Li SW, Wong LY, et al: Randomized controlled trial of vitamin D supplement on endothelial function in patients with type 2 diabetes. Atherosclerosis 2013;227:140-146.

66 Breslavsky A, Frand J, Matas Z, Boaz M, Barnea Z, Shargorodsky M: Effect of high doses of vitamin D on arterial properties, adiponectin, leptin and glucose homeostasis in type 2 diabetic patients. Clin Nutr 2013;32:970975.

67 Scragg R, Khaw KT, Murphy S: Effect of winter oral vitamin D3 supplementation on cardiovascular risk factors in elderly adults. Eur J Clin Nutr 1995;49:640-646.

68 Scragg R, Slow S, Stewart AW, Jennings LC, Chambers ST, Priest PC, et al: Long-term high-dose vitamin D3 supplementation and blood pressure in healthy adults: a randomized controlled trial. Hypertension 2014;64: 725-730.

69 Witham MD, Dove FJ, Sugden JA, Doney AS, Struthers AD: The effect of vitamin D replacement on markers of vascular health in stroke patients - a randomised controlled trial. Nutr Metab Cardiovasc Dis 2012;22:864870. 
Veloudi et al.: Effectiveness of Vitamin D Supplementation for Cardiovascular Health Outcomes

70 Dreyer G, Tucker AT, Harwood SM, Pearse RM, Raftery MJ, Yaqoob MM: Ergocalciferol and microcirculatory function in chronic kidney disease and concomitant vitamin D deficiency: an exploratory, double blind, randomised controlled trial. PLoS One 2014;9:e99461.

71 Marckmann P, Agerskov H, Thineshkumar S, Bladbjerg EM, Sidelmann JJ, Jespersen J, et al: Randomized controlled trial of cholecalciferol supplementation in chronic kidney disease patients with hypovitaminosis D. Nephrol Dial Transplant 2012;27:3523-3531.

72 Stricker H, Bianda FT, Guidicelli-Nicolosi S, Limoni C, Colucci G: Effect of a single, oral, high-dose vitamin D supplementation on endothelial function in patients with peripheral arterial disease: a randomised controlled pilot study. Eur J Vasc Endovasc Surg 2012;44:307-312.

73 Witham MD, Dove FJ, Khan F, Lang CC, Belch JJ, Struthers AD: Effects of vitamin D supplementation on markers of vascular function after myocardial infarction - a randomised controlled trial. Int J Cardiol 2013;167:745749.

74 Dong Y, Stallmann-Jorgensen IS, Pollock NK, Harris RA, Keeton D, Huang Y, et al: A 16-week randomized clinical trial of 2,000 international units daily vitamin D3 supplementation in black youth: 25-hydroxyvitamin D, adiposity, and arterial stiffness. J Clin Endocrinol Metab 2010;95:4584-4591.

75 Martins DM, Meng YX, Tareen N, Artaza J, Lee JE, Farodolu C, Gibbons G, Norris K: The effect of short term vitamin D supplementation on the inflammatory and oxidative mediators of arterial stiffness. Health (Irvine Calif) 2014;6:1503-1511.

76 Jorde R, Sneve M, Torjesen P, Figenschau Y: No improvement in cardiovascular risk factors in overweight and obese subjects after supplementation with vitamin D3 for 1 year. J Intern Med 2010;267:462-472.

77 Veloudi P, Blizzard CL, Ding CH, Cicuttini FM, Jin X, Wluka AE, et al: Effect of vitamin D supplementation on aortic stiffness and arterial hemodynamics in people with osteoarthritis and vitamin D deficiency. J Am Coll Cardiol 2015;66:2679-2681.

78 Daly RM, Nowson CA: Long-term effect of calcium-vitamin D(3) fortified milk on blood pressure and serum lipid concentrations in healthy older men. Eur J Clin Nutr 2009;63:993-1000.

79 Forman JP, Scott JB, Ng K, Drake BF, Suarez EG, Hayden DL, et al: Effect of vitamin D supplementation on blood pressure in blacks. Hypertension 2013;61:779-785.

80 Kollias A, Lagou S, Zeniodi ME, Boubouchairopoulou N, Stergiou GS: Association of central versus brachial blood pressure with target-organ damage: systematic review and meta-analysis. Hypertension 2016;67:183190.

81 Beveridge LA, Struthers AD, Khan F, Jorde R, Scragg R, Macdonald HM, et al: Effect of vitamin D supplementation on blood pressure: a systematic review and meta-analysis incorporating individual patient data. JAMA Intern Med 2015;175:745-754.

82 Sharman J, Stowasser M, Fassett R, Marwick T, Franklin S: Central blood pressure measurement may improve risk stratification. J Hum Hypertens 2008;22:838-844.

83 Larsen T, Mose FH, Bech JN, Hansen AB, Pedersen EB: Effect of cholecalciferol supplementation during winter months in patients with hypertension: a randomized, placebo-controlled trial. Am J Hypertens 2012;25:12151222.

84 McGreevy C, Barry M, Davenport C, Byrne B, Donaghy C, Collier G, et al: The effect of vitamin D supplementation on arterial stiffness in an elderly community-based population. J Am Soc Hypertens 2015;9:176-183.

85 Zaleski A, Panza G, Swales H, Arora P, Newton-Cheh C, Wang T, et al: High-dose versus low-dose vitamin D supplementation and arterial stiffness among individuals with prehypertension and vitamin D deficiency. Dis Markers 2015;2015:918968.

86 Braam LA, Hoeks AP, Brouns F, Hamulyak K, Gerichhausen MJ, Vermeer C, Beneficial effects of vitamins D and $\mathrm{K}$ on the elastic properties of the vessel wall in postmenopausal women: a follow-up study. Thromb Haemost 2004;91:373-380.

87 Harris RA, Pedersen-White J, Guo DH, Stallmann-Jorgensen IS, Keeton D, Huang Y, et al: Vitamin D3 supplementation for 16 weeks improves flow-mediated dilation in overweight African-American adults. Am J Hypertens 2011;24:557-562.

88 Sokol SI, Srinivas V, Crandall JP, Kim M, Tellides G, Lebastchi AH, et al: The effects of vitamin D repletion on endothelial function and inflammation in patients with coronary artery disease. Vasc Med 2012;17:394-404.

89 Longenecker CT, Hileman CO, Carman TL, Ross AC, Seydafkan S, Brown TT, et al: Vitamin D supplementation and endothelial function in vitamin D deficient HIV-infected patients: a randomized placebo-controlled trial. Antivir Ther 2012;17:613-621.

90 Thethi TK, Bajwa MA, Ghanim H, Jo C, Weir M, Goldfine AB, et al: Effect of paricalcitol on endothelial function and inflammation in type 2 diabetes and chronic kidney disease. J Diabetes Complications 2015;29:433-437.

91 Holland DJ, Sacre JW, McFarlane SJ, Coombes JS, Sharman JE: Pulse wave analysis is a reproducible technique for measuring central blood pressure during hemodynamic perturbations induced by exercise. Am J Hypertens 2008;21:1100-1106

92 Pilz S, Gaksch M, Kienreich K, Grubler M, Verheyen N, Fahrleitner-Pammer A, et al: Effects of vitamin D on blood pressure and cardiovascular risk factors: a randomized controlled trial. Hypertension 2015;65:11951201.

93 Margolis KL, Ray RM, Van Horn L, Manson JE, Allison MA, Black HR, et al: Effect of calcium and vitamin D supplementation on blood pressure: the Women's Health Initiative Randomized Trial. Hypertension 2008;52: 847-855. 
Veloudi et al.: Effectiveness of Vitamin D Supplementation for Cardiovascular Health Outcomes

94 Arora P, Song Y, Dusek J, Plotnikoff G, Sabatine MS, Cheng S, et al: Vitamin D therapy in individuals with prehypertension or hypertension: the DAYLIGHT trial. Circulation 2015;131:254-262.

95 Witham MD, Price RJG, Struthers AD, Donnan PT, Messow M, McConnachie A, et al: Effect of vitamin D supplementation on orthostatic hypotension: data from the Vitamin D in Isolated Systolic Hypertension randomized controlled trial. J Hypertens 2014;32:1693-1699.

96 Witham MD, Price RJG, Struthers AD, Donnan PT, Messow CM, Ford I, McMurdo MET: Cholecalciferol treatment to reduce blood pressure in older patients with isolated systolic hypertension: the VitDISH randomized controlled trial. JAMA Intern Med 2013;173:1672-1679.

97 Zittermann A, Frisch S, Berthold HK, Gotting C, Kuhn J, Kleesiek K, et al: Vitamin D supplementation enhances the beneficial effects of weight loss on cardiovascular disease risk markers. Am J Clin Nutr 2009;89:13211327.

98 Orwoll ES, Oviatt S: Relationship of mineral metabolism and long-term calcium and cholecalciferol supplementation to blood pressure in normotesnive men. Am J Clin Nutr 1990;52:712-721.

99 Heaney RP: Guidelines for optimizing design and analysis of clinical studies of nutrient effects. Nutr Rev 2014; 72:48-54.

100 Kennel KA, Drake MT, Hurley DL: Vitamin D deficiency in adults: when to test and how to treat. Mayo Clin Proc 2010;85:752-757; quiz 757-758.

101 Houghton LA, Vieth R: The case against ergocalciferol (vitamin D2) as a vitamin supplement. Am J Clin Nutr 2006;84:694-697.

102 Chao YS, Brunel L, Faris P, Veugelers PJ: The importance of dose, frequency and duration of vitamin D supplementation for plasma 25-hydroxyvitamin D. Nutrients 2013;5:4067-4078.

103 Holick MF, Binkley NC, Bischoff-Ferrari HA, Gordon CM, Hanley DA, Heaney RP, et al: Evaluation, treatment, and prevention of vitamin D deficiency: an Endocrine Society clinical practice guideline. J Clin Endocrinol Metab 2011;96:1911-1930.

104 Miettinen ME, Kinnunen L, Leiviska J, Keinanen-Kiukaanniemi S, Korpi-Hyovalti E, Niskanen L, et al: Association of serum 25-hydroxyvitamin D with lifestyle factors and metabolic and cardiovascular disease markers: population-based cross-sectional study (FIN-D2D). PLoS One 2014;9:e100235.

105 Mai XM, Chen Y, Camargo CA Jr, Langhammer A: Cross-sectional and prospective cohort study of serum 25-hydroxyvitamin D level and obesity in adults: the HUNT study. Am J Epidemiol 2012;175:1029-1036.

106 Yoshimura N, Muraki S, Oka H, Tanaka S, Kawaguchi H, Nakamura K, Akune T: Accumulation of metabolic risk factors such as overweight, hypertension, dyslipidaemia, and impaired glucose tolerance raises the risk of occurrence and progression of knee osteoarthritis: a 3-year follow-up of the ROAD study. Osteoarthr Cartilage 2012;20:1217-1226.

107 Witham MD, Nadir MA, Struthers AD: Effect of vitamin D on blood pressure: a systematic review and metaanalysis. J Hypertens 2009;27:1948-1954.

108 Pittas AG, Chung M, Trikalinos T, Mitri J, Brendel M, Patel K, et al: Systematic review: vitamin D and cardiometabolic outcomes. An Intern Med 2010;152:307-314.

109 Kunutsor SK, Burgess S, Munroe PB, Khan H: Vitamin D and high blood pressure: causal association or epiphenomenon? Eur J Epidemiol 2014;29:1-14.

110 Wu SH, Ho SC, Zhong L: Effects of vitamin D supplementation on blood pressure. South Med J 2010;103:729737.

111 Lee KJ, Lee YJ: Effects of vitamin D on blood pressure in patients with type 2 diabetes mellitus. Int J Clin Pharmacol Ther 2016;54:233-242.

112 Hussin AM, Ashor AW, Schoenmakers I, Hill T, Mathers JC, Siervo M: Effects of vitamin D supplementation on endothelial function: a systematic review and meta-analysis of randomised clinical trials. Eur J Nutr 2016, Epub ahead of print.

113 Upala S, Sanguankeo A, Congrete S, Jaruvongvanich V: Effect of cholecalciferol supplementation on arterial stiffness: a systematic review and meta-analysis. Scand Cardiovasc J 2016;50:230-235.

114 Rodriguez AJ, Scott D, Srikanth V, Ebeling P: Effect of vitamin D supplementation on measures of arterial stiffness: a systematic review and meta-analysis of randomised controlled trials. Clin Endocrinol 2016;84: 645-657.

115 Manson JE, Bassuk SS: Vitamin D research and clinical practice: at a crossroads. JAMA 2015;313:1311-1132.

116 Witham MD, Ireland S, Houston JG, Gandy SJ, Waugh S, MacDonald TM, et al: Vitamin D therapy to reduce blood pressure and left ventricular hypertrophy in resistant hypertension: randomized, controlled trial. Hypertension 2014;63:706-712.

117 Pan WH, Wang CY, Li LA, Kao LS, Yeh SH: No significant effect of calcium and vitamin D supplementation on blood pressure and calcium metabolism in elderly Chinese. Chin J Physiol 1993;36:85-94.

118 Lind L, Wengle B, Wide L, Ljunghall S: Reduction of blood pressure during long-term treatment with active vitamin D (alphacalcidol) is dependent on plasma renin activity and calcium status. A double-blind, placebocontrolled study. Am J Hypertens 1989;2:20-25. 